\title{
Regional Growth Differential in Manufacturing Employment: The Case of the Province of Ontario, Canada
}

\author{
Andreas A. Andrikopoulos*
}

\section{INTRODUCTION}

Many countries have become aware in recent years of the existence of growth differential rates among regions that has led either to some kind of inequalities in regional standards of living in certain regions or, and more important, to culture and social structural inequalities in other regions. In order to ameliorate these inequalities through government policies, the causes that create regional growth differentials should be identified. The shift-share model was thought by many to be an effective tool for predicting regional economic growth and structure. Yet, as investigations by Brown (1969), Houston (1967) and others have shown, the model does not provide a convincing explanation as to why the industrial structure of a region is different from the national structure or to why the growth (decline) of the industries in the region is different from the national average. They challenge the theoretical content of the model. Houston (1967), for example, observed that

.... To be useful in explaining regional growth, there should be some theoretical basis for identifying the three separate components. A theory of regional economic growth would require that they be entered as endogenous variables in behavioural equations, and that ... supply changes, demand shifts, any or all of these, may be behind either component. ...

The controversy concerning both the conceptual and practical strengths and weaknesses of the model has been widely discussed in the field of regional economics ${ }^{1}$. The literature does not lack either attempts or suggestions regarding testable hypotheses which are consistent with economic theory and managable at regional level. Recent investigations by Hellman (1976) and Chalmers and Beckhelm (1976), for example, have set a new theoretical foundation in the analysis of regional economic growth by challenging the contention that the "differential shift is not a useful concept because it cannot be given behavioral content" (Chalmers and Beckhelm, 1976, p. 21). These studies confirmed the fact that the major factor in location and locational changes of firms is the spatial variation in profits (Chalmers and Beckhelman, 1976) and agglomeration economies (Hellman, 1976). This suggests that the differential shift (regional-share) 
in certain industries would be explained by variables that would be expected to affect the spatial veriation in profits. Although these studies constitute a valuable contribution to the literature in the field of regional economic growth, they do not overcome all limitations (the source and quality of data, the choice of the base and terminal years, the level of industry aggregation, etc.), that may have seriously influence their results.

It is the purpose of this paper, therefore, to formulate testable hypotheses concerning the shift components of manufacturing employment in the province of Ontario, Canada. Like many other relevant studies, the one set out in this paper draws upon several elements that have been utilized elsewhere. It does, however, break away from the traditional approaches in the sense that it introduces new explanatory variables of the shift components and, additionally, provides a thorough investigation of the growth components of employment on an industry-by-industry basis using time-series data.

\section{THE THEORETICAL MODEL}

The Shift-Share Model:

Formally, the shift-share model can be summarized by the following identity:

$$
\Delta \mathrm{L}=\sum_{\mathrm{i}=1}^{\mathrm{m}} \mathrm{r}_{\mathrm{oo}} \mathrm{e}_{\mathrm{ij}}+\sum_{\mathrm{i}=1}^{\mathrm{m}}\left(\mathrm{r}_{\mathrm{io}}-\mathrm{r}_{\mathrm{oo}}\right) \mathrm{e}_{\mathrm{ij}}+\sum_{\mathrm{i}=1}^{\mathrm{m}}\left(\mathrm{r}_{\mathrm{ij}}-\mathrm{r}_{\mathrm{io}}\right) \mathrm{e}_{\mathrm{ij}}
$$

where $e_{i j}$ is the employment in the $i$ industry and $\mathrm{j}$ region, $\mathrm{r}_{\mathrm{oo}}$ is the actual rate of growth in employment nationally, $r_{i o}$ is the actual rate of growth in the entire $i$ industry, and $r_{i j}$ is the rate of growth in employment in the $i$ industry regionally. In the present analysis i ranges over $m$ industrial sectors. The term $\Delta \mathrm{L}$ measures the actual change in employment regionally. The first term of the right-hand side of the identity is the so-called national growth component. It is defined as the growth that would have occured in the region if employment in all industries had grown at the same rate as the national average, $\mathrm{r}_{00}$. The second component in the identity is termed industrial-mix. It is a measure of the employment change determined by the types of industries located in the region. More specifically, this component may be thought of as a growth industry concept which measures the growth in employment in the region that is due either to the fact that the region is characterized by a predominance of national rapid growth industries (positive industrial-mix) or to the fact that the region specializes in slow growth or declining industries at the national level (negative industrial-mix). The third component in the identity is the so-called regional-share component. This component measures the extent to which additional employment growth in a specific industry is the result of that industry growing in the region at a rate different from the national rate of change. It reflects the existence of regional or locational advantages 
(disadvantages) that allow industries in the region to grow at faster (slower) rates than they would in other regions. It is, therefore, considered to be the dynamic element of growth in employment; thus more important for regional planning and development. The region's changing position relative to the rest of the country is given by the "net relative change" which is the sum of the industrial-mix and regional-share component ${ }^{2}$. The significance of the shift-share model centers around the fact that it summarizes the effects of three major factors on the growth of employment in a particular industry or region: (1) national factors $\left(\mathrm{r}_{\mathrm{oo}}\right.$, and $\left.\mathrm{r}_{\mathrm{io}}\right)$; (2) local factors $\left(r_{i j}\right)$; and (3) differential factors $\left(r_{i j}-r_{i o}\right)$. In other words, it demonstrates that the growth of a region's economy can be looked upon as a combination of exogenous or national factors, the region's initial economic structure and size, and differential factors. The shift-share model is utilized in this analysis in order to identify the growth components of employment and, therefore, to formulate two basic hypotheses: The regional-share hypothesis, and the industrial-mix hypothesis.

\section{The Hypotheses:}

The shift-share model ${ }^{3}$ does not provide, by itself, a clear-cut answer as to how regions grow and to what extent interregional growth differences can be explained. It, simply, measures the employment implications for a region not having national performance in the various industries (Martin, 1976). The extensive literature in the field failed, more or less, to supply convincing evidence regarding the causal relationships between the growth components of employment and the underlying regional factors, since neither regression analysis approaches (Brown, 1969) nor analysis of variance techniques (Buck, 1975) have provided meaningful results in most of the cases in which the model has been tested. Admittedly enough, the unsatisfactory performance of the model in the past is attributed to the unstable character of the two shift components (Brown, 1969) and, more important, to the wrong specification of the explanatory variables used (Chalmers and Beckhelms, 1976). In order to improve the performance of the model and to take into account some of its past shortcomings and deficiencies, the hypotheses are formulated on an a priori theoretical basis and tested for a relatively long time span.

The Regional-Share Hypothesis: On the basis of evidence provided by other recent studies (Chalmers and Beckhelm, 1976, and Hellman, 1976) and the simple theoretical foundation of the shift-share model, we postulate that the regional-share hypothesis relates the industry's regional-share component of employment to four basic sets of regional factors: region's economic condition and market size, agglomeration economies, capital formation, and the "share" variable. The region's economic conditions are measured by relative wage rates $\left[\left(\mathrm{W}_{0} / \mathrm{W}_{\mathrm{C}}\right)_{\mathrm{ij}}\right]^{4}$, relative regional unemployment rates $\left[\left(\mathrm{U}_{0} / \mathrm{U}_{\mathrm{c}}\right)\right]$, and relative income $\left[\left(\mathrm{Y}_{\mathrm{o}} / \mathrm{Y}_{\mathrm{c}}\right)\right]$. Region's market size $\left[\left(\mathrm{P}_{0} / \mathrm{P}_{\mathrm{c}}\right)\right]$, on the other hand, is measured by province's population $\left(\mathrm{P}_{\mathrm{o}}\right)$ relative to nation's $\left(P_{c}\right)$ population (Hellman, 1976). Variables with both $i$ and $\mathrm{j}$ subscript are specific to both industry and province. The subscripts 
"o" and "c" indicate Ontario and Canada, respectively. These variables are evaluated at the beginning of the period ( $\mathrm{t}-1)$ and, other things being equal, the effect of the wage and unemployment variables are expected to be negative while the market size and income variables are expected to be positive. Two alternative indices are used to measure agglomeration economies $\left(\mathrm{I}_{\mathrm{A}}\right)$ : The Klaasen (1973) resource-dependency coefficient; and the one suggested in the literature by Hellman (1976). The first index is defined by the ratio of the value added in the $\mathrm{i}$ industry in the $\mathrm{j}$ region $\left[(\mathrm{V} . \mathrm{A})_{\mathrm{ij}}\right]$ to the value of shipments $\left[(\mathrm{V} . \mathrm{S})_{\mathrm{ij}}\right]$ in the corresponding industry and region. According to Klaasen's interpretation, the lower the ratio the more dependent the industry is on external resources. This suggests that a value of the coefficient equal to one indicates that the industry is completely integrated so that it purchases no inputs whatsoever from other sectors. The second index of agglomerations economies measures external economies available in the province which are internal to industry $i\left(a_{i j} E_{i j}\right)$. It was calculated at the beginning of the period $(\mathrm{t}-1)$ by weighting the regional employment in industry $\mathrm{i}\left(\mathrm{E}_{\mathrm{ij}}\right)$ by the input-output technical coefficients $\left(\mathrm{a}_{\mathrm{ij}}\right)$ from 1961-1972 input-output Tables. One might argue that region's relative population can be thought of as a proxy variable for local consumer markets and the agglomeration index as a proxy variable for intermediate markets. The share variable $\left(E_{i j} / E_{j}\right)$, defined as the ratio between the employment in industry i in Ontario $\left(\mathrm{E}_{\mathrm{ij}}\right)$ and the employment in the same industry $\left(\mathrm{E}_{\mathrm{i}}\right)$ nationally was introduced into the hypothesis in order to capture the effect of competition among the suppliers in the province. Other things being equal, the effect of the share variable on the industry's regional-share component is expected to be negative (Beckhelm and Chalmers, 1976).

Nevertheless, one should agree that the number of variables that can be put in the hypothesis to measure the "attractiveness" of the province is not limited by the model itself. It is rather to be limited by the information that can be easily obtained. In recent years, capital formation was seen as the main determinant of economic growth. In the light of this argument, there has been a growing recognition that it is possible to explain part of regional economic growth by factors that may have created the regional comparative advantage (disadvantage). Stillwell (1968), for example, suggested that either infrastructure investment and/or the distribution of industrial capital should be considered as explanatory variables of the regional-share component. In order to provide an addition to the literature in the field, capital formation was also put into the regional-share hypothesis. The natural of capital formation (social capital versus private capital) and the conceptual aspects of the manner in which it enters the hypothesis has been a matter of some debate. Depending upon the relative availability of data, five types of capital formation (I) were introduced, one at a time, in the hypothesis: industrial distribution of capital formation $\left[\left(\mathrm{I}_{\mathrm{o}} / \mathrm{I}_{\mathrm{c}}\right)_{\mathrm{M}}\right]$, the level $\left[\left(\mathrm{I}_{0}\right)_{\mathrm{ij}}\right]$, distribution $\left[\left(\mathrm{I}_{0} / \mathrm{I}_{\mathrm{c}}\right)_{\mathrm{i}}\right]$ and change $\left[(\Delta \mathrm{I})_{\mathrm{ij}}\right]$ of capital formation in the industry $i$, and the distribution of the overall capital formation $\left[\left(\mathrm{I}_{\mathrm{o}} / \mathrm{I}_{\mathrm{c}}\right)_{\mathrm{T}}\right]^{5}$. Variables with both $\mathrm{i}$ and $\mathrm{j}$ subscript are specific to both industry and province, and the subscripts "o" and "c" indicate Ontario and Canada, 
respectively. The causal relationship between the regional-share component and the capital formation variables is not clear. What can be said with certainty is that the effect of capital formation on the regional-share component will vary (positive or negative) with the individual industry, the factor substitutability (neoclassical theme), and the extent to which new capital replaces one type of production with another.

The Industrial-Mix Hypothesis: Although the industrial-mix hypothesis has been discredited repeatedly in the past, it inspires further investigation. In the light of the fact that the industrial-mix component of the model "takes into account the structural nature of the region's growth; that is, its predisposition to grow slow or quickly according to its make-up" (Paris, 1970), it has been argued (Martin, 1976) that "the industrial-structure of a region as well as its performance during the period being discussed are the results of two groups of factors, one being of a historical nature, reflecting the effects of past economic movements on the region's actual economic condition" (quality of human resources, infrastructure of transportation and communication services, extent of market, etc.), "the other being of a current or contemporary nature, taking into account the effects of structural changes under way." This suggests that these two sets of factors are not independent of each other since past performance of the region affects current regional conditions and structure. In the spirit of this argument and in line with the theoretical foundation of the model, we assume that the industrial-mix component of employment should be affected either by policy manipulated variables-that is variables that could inject fast growing industries in the province in order to compensate for their above average of declining industries (e.g., policies that act on the regional distribution of industrial capital) and/or variables exogenous to the regionthat is national variables affecting demand and supply (Mattila, 1966). 1966). Nevertheless, one should note that some of the variables reflecting regional structure need not be different from those related to the regional-share component because by handling one of these components satisfactory (i.e., explaining and therefore predicting it), the other becomes a residual. This suggests that the region's economic conditions and market size as well as its built-up in the past (share variable) should enter in the hypothesis. In an essense, the same explanatory variables used in the regional-share hypothesis can be also used as explanatory factors of the industrial-mix component. It is essential to notice that the effect of $E_{i j} / E_{i}$ is expected to be positive, particularly to the fast growing industries in the province. The investigator should be aware of this when making the transition from statistical data to explanatory analysis.

\section{APPLICATION OF THE MODEL}

The Shift-Share Model:

The shift-share model was estimated for the Province of Ontario, Canada. The basic data are employment figures in the two-digit manufacturing industry (Statistics of Canada, various issues) covering the period 
TABLE 1: Shift-Share Model: Components of Growth in Manufacturing Employment, Ontario 1961 Through 1973

\begin{tabular}{|c|c|c|c|c|c|c|c|c|c|c|}
\hline \multirow[b]{2}{*}{ Year } & \multicolumn{2}{|c|}{ Actual Change } & \multicolumn{2}{|c|}{ National Growth } & \multicolumn{2}{|c|}{ Industrial-Mix } & \multicolumn{2}{|c|}{ Regional-Share } & \multicolumn{2}{|c|}{ Net-Relative Change } \\
\hline & Employees & $\%$ & Employees & $\%$ & Employees & $\%$ & Employees & $\%$ & Employees & $\%$ \\
\hline & 1 & 2 & 3 & 4 & 5 & 6 & 7 & 8 & 9 & 10 \\
\hline $1961-62$ & 23127 & 5.30 & 16117 & 3.72 & 3146 & 0.73 & 3863 & 0.89 & 7009 & 1.62 \\
\hline $1962-63$ & 32184 & 4.90 & 13666 & 3.00 & 1328 & 0.29 & 17190 & 3.77 & 18518 & 4.06 \\
\hline $1963-64$ & 21388 & 6.56 & 26247 & 5.37 & 3428 & 0.68 & -8108 & -1.69 & -4859 & -1.01 \\
\hline $1964-65$ & 33175 & 6.62 & 28146 & 5.52 & 4761 & 0.93 & 267 & 0.05 & 5029 & 0.98 \\
\hline $1965-66$ & 35626 & 6.45 & 27757 & 5.11 & 5166 & 0.95 & 2702 & 0.05 & 7868 & 1.45 \\
\hline $1966-67$ & -7453 & -1.28 & -2117 & -0.37 & 477 & 0.08 & -5813 & -1.00 & -5335 & -0.92 \\
\hline $1967-68$ & -7329 & -1.28 & -4117 & -0.72 & -996 & -0.17 & -2215 & -0.39 & -3211 & -0.56 \\
\hline $1968-69$ & 10969 & 1.94 & 14413 & 2.56 & 2054 & 0.36 & -5498 & -0.96 & -3444 & -0.60 \\
\hline $1969-70$ & -11888 & -2.06 & -11025 & -1.92 & -1176 & -0.21 & 312 & 0.06 & -863 & -0.15 \\
\hline $1970-71$ & 1006 & 1.79 & 360 & 0.06 & -1828 & -0.32 & 2473 & 0.44 & 645 & 0.12 \\
\hline $1971-72$ & 20068 & 3.56 & 21871 & 3.88 & 17774 & 3.14 & -19547 & -3.47 & -1803 & -0.32 \\
\hline $1972-73$ & 33023 & 5.65 & 30267 & 5.18 & 3509 & 0.60 & -753 & -0.13 & 2756 & 0.47 \\
\hline
\end{tabular}


1961-1973. Table 1 summarizes the growth patterns of employment from 1961 through 1973. This Table indicates that, with exception of three years (1966-67, 1967-68, and 1969-70) where the actual growth was negative, although smaller than the national average, the actual change balance was positive. The divergence between provincial (Table 1, columns 1 and 2) and national (Table 1, columns 3 and 4) growth patterns, however, can be analyzed in terms of the two shift components. A casual inspection of these two components (Table 1, columns 5, 6, 7, and 8) suggests that the province, on the average, has a sound ground for further growth and development. This is indicated by the fact that in only three years (1967-68, 1969-70, and 1970-71) the industrial-mix component was negative. This should not be interpreted as indicating that all industries in the province are fast-growing industries (Table 2). On the contrary, the over-all positive industrial-mix effect is mainly due to highly concentrated industries; that is to the export-oriented industries (e.g., industries with location quotient greater than one $)^{6}$. With the exception of three years, the industrial-mix component for the export-oriented industries was strong enough to outbalance the negative effect of the local industries (e.g., industries with location quotient less than one). Nevertheless, the regional-share component (Table 1, columns 7 and 8 ) and the overall net relative-change (Table 1, columns 9 and 10) perform less impressive. This may suggest that other provinces (e.g., British Columbia, Alberta, etc.) are able to compete successfully with Ontario to obtain certain manufacturing industries either because of sufficient local markets and/or the favourable environment these provinces provide to certain individual industries. This should not be taken as an indication of a declining importance the province of Ontario plays in the overall structure of the Canadian economy. Edwards, for example, argues that Ontario is "prominent as the only province with a positive industrial-mix component which is reflection of its unique position in Canada in terms of national employment and the fact that its industrial structure acts as the 'pace-setter' for the remainder of the country" (Edwards, 1976, p. 311). This argument further suggests that the negative industrial-mix effect in certain years is a reflection of the cyclical fluctuations the overall Canadian economy has been experiencing the last decade. The province is still promising in attracting manufacturing activities when it is compared to other individual provinces, rather than the nation as a whole.

The patterns of the annual changes in employment, on an industry-byindustry basis, are summarized in Table 2. This Table shows the direction (plus or minus) of the three shift components in employment (industrialmix, regional-share, and net-relative change). On the average, half of the industries or more have experienced both positive industrial-mix and regional-share shifts. Nevertheless, a complete understanding of the observed shifts requires to probe deeper into the factors that are behind these shifts. This task is undertaken, more or less, in the following section.

The Hypotheses:

Tables 3 and 4 summarize the results obtained from the stepwise regres- 
TABLE 2: Shift-Share Model: Components of Growth in

Manufacturing Employment, Ontario, 1961 Through 1973

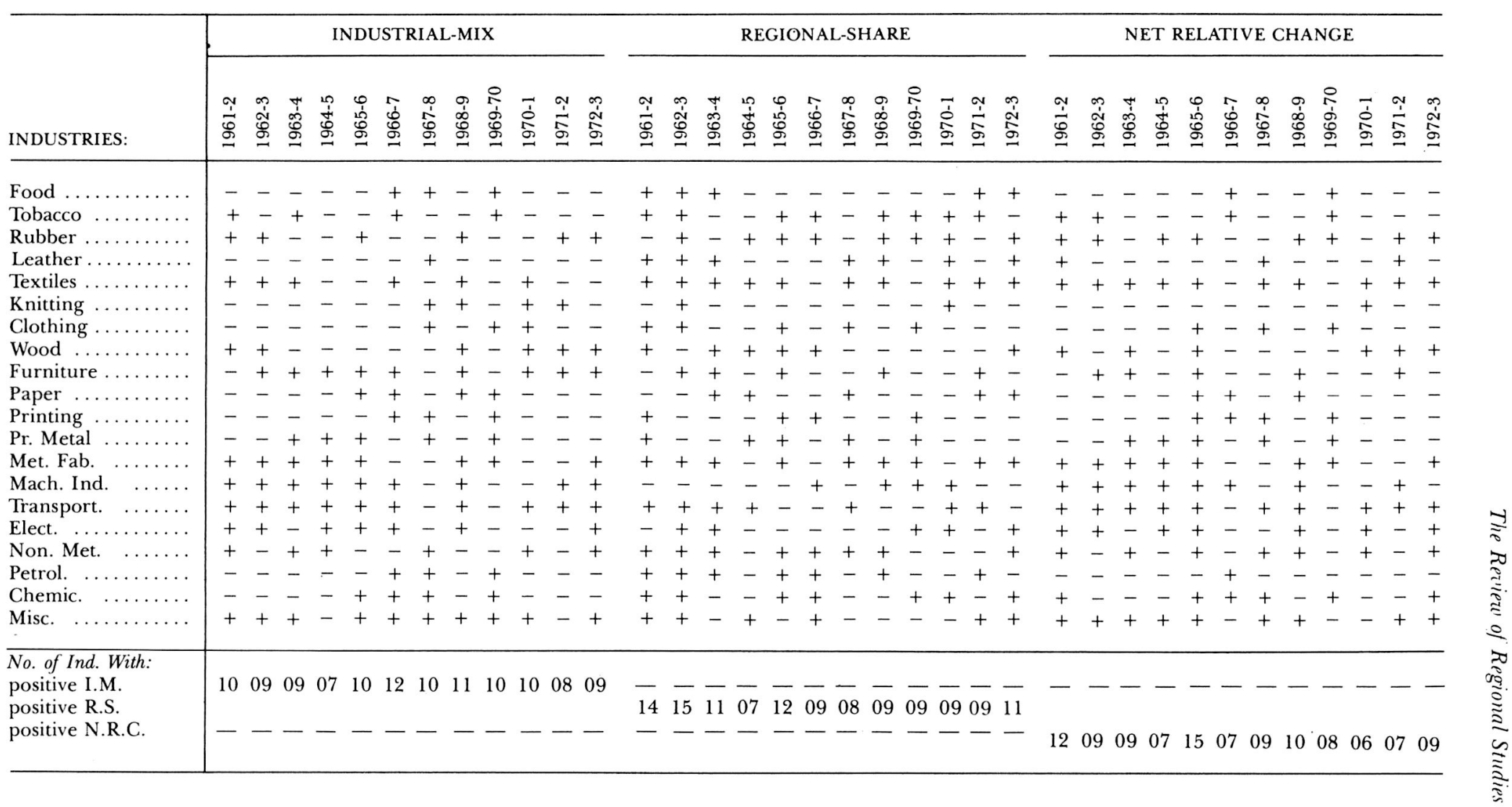


sions for each manufacturing industry and the province of Ontario as a whole. Following Chalmers and Beckhelm's analysis (1976), the procedure used to select among the possible explanatory variables consisted of two steps. First, the two shift components (regional-share and industrial-mix) for each industry were regressed on $\mathrm{E}_{\mathrm{ij}} / \mathrm{E}_{\mathrm{i}}, \mathrm{P}_{\mathrm{o}} / \mathrm{P}_{\mathrm{c}}, \mathrm{W}_{\mathrm{o}} / \mathrm{W}_{\mathrm{c}}, \mathrm{U}_{\mathrm{o}} / \mathrm{U}_{\mathrm{c}}, \mathrm{Y}_{\mathrm{o}} / \mathrm{Y}_{\mathrm{c}}, \mathrm{I}_{\mathrm{A}}$ and one at a time of the capital formation variables $\left[\left(\mathrm{I}_{0}\right)_{\mathrm{ij}},\left(\mathrm{I}_{\mathrm{o}} / \mathrm{I}_{\mathrm{c}}\right) \mathrm{i},\left(\mathrm{I}_{\mathrm{o}} / \mathrm{I}_{\mathrm{c}}\right)_{\mathrm{M}}\right.$, $\left(\mathrm{I}_{\mathrm{v}} / \mathrm{I}_{\mathrm{c}}\right)_{\mathrm{T}}$, and $\left.\Delta\left(\mathrm{I}_{\mathrm{o}}\right)_{\mathrm{ij}}\right]$. The second step was to drop any variable that provides either a non-significant contribution or coefficient with an unanticipated sign and retain the combination of explanatory variables which is consistent with the hypotheses.

Table 3 presents the stepwise results for the regional-share hypothesis. These results indicate that the behavior of the regional-share component over time (1961 through 1973) is fairly explained in most of the industries by the spatial distribution of capital, the region's economic conditions and market size, agglomeration economies and the "share" variable. The equations as a whole are fairly satisfactory in terms of $\mathrm{R}^{2}$ 's, and the signs and significance of the coefficients. The chief point in these equations is the effect of $\mathrm{E}_{\mathrm{ij}} / \mathrm{E}_{\mathrm{i}}$. The coefficient of the share variable shows a negative sign and it is statistically significant in almost every industry in question. These findings confirm Chalmers and Beckhelm's (1976) conclusion that the supply potential variable, measured by the share variable, constitutes a good explanatory factor of the regional-share component.

Turning now to the other explanatory variables of the model, the region's market size in four industries (electrical product, non-metallic mineral, textile, and furniture and fixture industries); the relative wage rates in five industries (transportation, textile, clothing, paper and allied, and petroleum and coal industries); the relative unemployment rates in seven industries (rubber, machinery, non-metallic mineral, food and beverage, textile, furniture and fixture, and petroleum and coal industries); the relative income in three industries (knitting mills, clothing, and paper and allied industries); and agglomeration economies in five industries (metal fabricating, transportation, electrical product, clothing, and wood industries) were all found to have statistically significant coefficients at an acceptable probability level $(\mathrm{P} \leqq 0.10)$. However, it is perhaps more difficult to postulate any convincing argument regarding the direction (positive or negative) of the casual relationship between the regional-share component and some of these explanatory variable. In certain cases, for example, growth may start in secondary manufacturing where there is a pool of unemployed labor (Brewis, 1972, P.60). In other cases shortage of skilled labor in certain industries can be overcome through higher wages offered by the firms in sort of incentives to attract skilled personnel from other industries in the region or other regions in the country. In such cases, other things being equal, a positive relationship between regional-share component and relative industry's wage rates and/or relative unemployment rates should not be rejected.

Capital formation plays also a prominent role in explaining the industry's regional-share component. This is indicated by the fact that the level of investment in the $\mathrm{i}$ industry in the province in three sectors (machinery, 
TABLE 3

SHIFT-SHARE MODEL: REGIONAL-SHARE HYPOTHESIS

\begin{tabular}{|c|c|c|c|c|c|c|}
\hline \multirow[b]{2}{*}{ Industry Group } & \multirow{2}{*}{$\begin{array}{l}\text { Constant } \\
\text { Term }\end{array}$} & \multicolumn{5}{|c|}{ INDEPENDENT VARIABLES } \\
\hline & & $\left(\mathrm{E}_{\mathrm{ij}} / \mathrm{E}_{\mathrm{i}}\right)$ & $\left(\mathrm{P}_{\mathrm{o}} / \mathrm{P}_{\mathrm{c}}\right)$ & $\left(\mathrm{W}_{0} / \mathrm{W}_{\mathrm{c}}\right)_{\mathrm{U}}$ & $\left(\mathrm{U}_{\mathrm{o}} / \mathrm{U}_{\mathrm{c}}\right)$ & $\left(\mathrm{Y}_{\mathrm{w}} / \mathrm{Y}_{\mathrm{c}}\right)$ \\
\hline $\begin{array}{l}\text { ONTARIO: ALL } \\
\text { INDUSTRIES }\end{array}$ & -13.19 & $\begin{array}{r}-0.860 \\
(1.75)\end{array}$ & $\begin{array}{l}14.930 \\
(2.22)\end{array}$ & $\cdots$ & $\cdots$ & $\cdots$ \\
\hline $\begin{array}{l}\text { INDUSTRIES WITH } \\
\text { L. } Q>1 \text { (Total) }\end{array}$ & -2.31 & $\ldots$ & $\ldots$ & $\ldots$ & $\cdots$ & $\ldots$ \\
\hline Rubber Industries & 0.40 & $\cdots$ & $\cdots$ & $\cdots$ & $\begin{array}{c}-0.570 \\
(1.67)\end{array}$ & $\ldots$ \\
\hline $\begin{array}{l}\text { Printing/Publishing \& } \\
\text { Allied Industries }\end{array}$ & -0.03 & $\begin{array}{c}0.390 \\
(2.18)\end{array}$ & $\cdots$ & $\cdots$ & $\cdots$ & $\cdots$ \\
\hline Primary Product Industries & 0.36 & $\begin{array}{c}-0.390 \\
(2.18)\end{array}$ & $\cdots$ & $\cdots$ & $\cdots$ & $\cdots$ \\
\hline $\begin{array}{l}\text { Metal Fabricating } \\
\text { Industries }\end{array}$ & -0.32 & $\cdots$ & $\cdots$ & $\cdots$ & $\cdots$ & $\ldots$ \\
\hline Machinery Industries & 0.05 & $\ldots$ & $\ldots$ & $\cdots$ & $\begin{array}{c}-0.080 \\
(3.90)\end{array}$ & $\ldots$ \\
\hline Transportation Industries & -0.02 & $\begin{array}{c}-0.640 \\
(2.31)\end{array}$ & $\cdots$ & $\begin{array}{r}0.250 \\
(1.78)\end{array}$ & $\cdots$ & $\cdots$ \\
\hline $\begin{array}{l}\text { Electrical Product } \\
\text { Industries }\end{array}$ & -0.81 & $\begin{array}{r}-0.800 \\
(6.49)\end{array}$ & $\begin{array}{r}1.610 \\
(4.71)\end{array}$ & $\cdots$ & $\cdots$ & $\cdots$ \\
\hline $\begin{array}{l}\text { Non-Metallic Mineral } \\
\text { Industries }\end{array}$ & 0.003 & $\begin{array}{c}-0.390 \\
(5.99)\end{array}$ & $\begin{array}{c}0.590 \\
(3.56)\end{array}$ & $\cdots$ & $\begin{array}{r}-0.040 \\
(3.92)\end{array}$ & $\cdots$ \\
\hline $\begin{array}{l}\text { Chemical \& Chemical } \\
\text { Product Industries }\end{array}$ & 0.11 & $\begin{array}{c}-0.230 \\
(4.04)\end{array}$ & $\cdots$ & $\cdots$ & $\ldots$ & $\cdots$ \\
\hline $\begin{array}{l}\text { INDUSTRIES WITH } \\
\text { L. } Q<1 \text { (Total) }\end{array}$ & 1.06 & $\cdots$ & $\cdots$ & $\begin{array}{l}19.67 \mathrm{E}_{0} \\
(3.69)\end{array}$ & $\begin{array}{r}1.320 \\
(2.53)\end{array}$ & $\begin{array}{r}4.360 \\
(4.03)\end{array}$ \\
\hline $\begin{array}{l}\text { Food \& Beverage } \\
\text { Industries }\end{array}$ & -0.12 & $\cdots$ & $\cdots$ & $\cdots$ & $\begin{array}{r}0.060 \\
(2.36)\end{array}$ & $\cdots$ \\
\hline Tobacco Product Industries & -0.01 & $\begin{array}{c}-0.090 \\
(4.43)\end{array}$ & $\cdots$ & $\cdots$ & $\cdots$ & $\cdots$ \\
\hline Leather Industries & 0.08 & $\begin{array}{c}-0.230 \\
(3.45)\end{array}$ & $\ldots$ & $\cdots$ & $\ldots$ & $\ldots$ \\
\hline Textile Industries & -0.10 & $\begin{array}{r}-0.780 \\
(4.66)\end{array}$ & $\begin{array}{c}4.840 \\
(4.93)\end{array}$ & $\begin{array}{c}-0.080 \\
(1.85)\end{array}$ & $\begin{array}{r}-0.090 \\
(2.91)\end{array}$ & $\cdots$ \\
\hline Knitting Mills & -0.17 & $\cdots$ & $\ldots$ & $\cdots$ & $\cdots$ & $\begin{array}{c}0.200 \\
(2.64)\end{array}$ \\
\hline Clothing Industries & -0.52 & $\cdots$ & $\cdots$ & $\begin{array}{c}-0.230 \\
(2.72)\end{array}$ & $\cdots$ & $\begin{array}{r}0.430 \\
(1.97)\end{array}$ \\
\hline Wood Industries & -0.14 & $\ldots$ & $\ldots$ & $\ldots$ & $\ldots$ & $\ldots$ \\
\hline $\begin{array}{l}\text { Furniture \& Fixture } \\
\text { Industries }\end{array}$ & -0.10 & $\begin{array}{c}-0.540 \\
(6.28)\end{array}$ & $\begin{array}{c}0.720 \\
(4.48)\end{array}$ & $\cdots$ & $\begin{array}{c}-0.040 \\
(3.76)\end{array}$ & $\cdots$ \\
\hline $\begin{array}{l}\text { Paper \& Allied } \\
\text { Industries }\end{array}$ & 0.06 & $\begin{array}{r}-0.790 \\
(5.21)\end{array}$ & $\ldots$ & $\begin{array}{r}0.050 \\
(2.00)\end{array}$ & $\cdots$ & $\begin{array}{r}0.690 \\
(4.32)\end{array}$ \\
\hline $\begin{array}{l}\text { Petroleum \& Coal } \\
\text { Industries }\end{array}$ & -.20 & $\begin{array}{c}-0.590 \\
(5.91)\end{array}$ & $\cdots$ & $\begin{array}{r}-0.002 \\
(1.86)\end{array}$ & $\begin{array}{c}-0.004 \\
(3.33)\end{array}$ & $\cdots$ \\
\hline
\end{tabular}

Note: For a managable presentation of the findings, the regression coefficients have been multiplied by $10^{-5}$ with the exception those coefficients where the letter $E_{0}$ is attached. 
TABLE 3

SHIFT-SHARE MODEL: REGIONAL-SHARE HYPOTHESIS (Cont.)

\begin{tabular}{|c|c|c|c|c|c|c|c|}
\hline \multicolumn{5}{|c|}{ INDEPENDENT VARIABLES } & \multirow{2}{*}{$\mathrm{R}^{2}$} & \multirow{2}{*}{$\begin{array}{l}\text { Durbin } \\
\text { Watson d- } \\
\text { Statistic }\end{array}$} & \multirow{2}{*}{$\begin{array}{l}\text { Relationship } \\
\text { between I.M. } \\
\text { \& R.S (r) }\end{array}$} \\
\hline$\left(I_{A}\right)$ & $\left(I_{11}\right)_{11}$ & $\left(I_{\mathbb{w}} / I_{c}\right)_{i}$ & $\left(I_{\mathrm{t}} / I_{\mathrm{c}}\right)_{\mathrm{M}}$ & $\left(\mathbf{I}_{\mathrm{G}} / \mathbf{I}_{\mathrm{C}^{\prime}}\right)_{\mathrm{T}}$ & & & \\
\hline $\begin{array}{l}14.210 \\
(2.68)\end{array}$ & $\cdots$ & $\cdots$ & $\begin{array}{l}7.130 \\
(3.13)\end{array}$ & $\cdots$ & $0: 803$ & 2.729 & -0.602 \\
\hline $\begin{array}{c}0.020 \\
(1.78)\end{array}$ & ${ }^{\cdots}$ & $\ldots$ & $\begin{array}{c}4.630 \\
(2.59)\end{array}$ & $\ldots$ & 0.604 & 2.205 & -0.703 \\
\hline$\ldots$ & $\ldots$ & $\ldots$ & $\ldots$ & $\ldots$ & 0.218 & 2.218 & -0.934 \\
\hline$\cdots$ & $\cdots$ & $\cdots$ & $\cdots$ & $\begin{array}{c}-0.290 \\
(3.49)\end{array}$ & 0.732 & 2.154 & 0.310 \\
\hline$\cdots$ & $\cdots$ & $\cdots$ & $\begin{array}{c}0.440 \\
(2.01)\end{array}$ & $\ldots$ & 0.611 & 2.566 & 0.823 \\
\hline $\begin{array}{c}0.650 \\
(2.63)\end{array}$ & $\begin{array}{c}-1.64 \mathrm{E}_{\mathrm{l}} \\
(1.95)\end{array}$ & $\cdots$ & $\cdots$ & $\cdots$ & 0.449 & 2.583 & 0.471 \\
\hline$\ldots$ & $\begin{array}{l}3.43 \mathrm{E}_{1} \\
(2.18)\end{array}$ & $\ldots$ & $\cdots$ & $\ldots$ & 0.755 & 1.492 & 0.383 \\
\hline $\begin{array}{l}-0.18 \mathrm{E}_{\text {, }} \\
(2.75)\end{array}$ & $\begin{array}{c}0.350 \\
(2.68)\end{array}$ & $\ldots$ & $\ldots$ & $\ldots$ & 0.702 & 2.124 & 0.325 \\
\hline $\begin{array}{l}0.850 \\
(5.92)\end{array}$ & $\ldots$ & $\ldots$ & $\begin{array}{c}0.750 \\
(5.38)\end{array}$ & $\ldots$ & 0.889 & 1.989 & -0.031 \\
\hline$\cdots$ & $\cdots$ & $\begin{array}{c}0.030 \\
(4.90)\end{array}$ & $\cdots$ & $\cdots$ & 0.878 & 2.612 & -0.212 \\
\hline$\ldots$ & $\ldots$ & $\begin{array}{c}0.030 \\
(4.40)\end{array}$ & $\ldots$ & $\ldots$ & 0.767 & 1.400 & -0.181 \\
\hline$\cdots$ & $\cdots$ & $\ldots$ & $\cdots$ & $\begin{array}{c}-2.220 \\
(3.56)\end{array}$ & 0.835 & 2.180 & -0.846 \\
\hline$\cdots$ & $\ldots$ & $\begin{array}{c}0.160 \\
(2.25)\end{array}$ & $\ldots$ & $\ldots$ & 0.418 & 2.515 & -0.617 \\
\hline$\cdots$ & $\cdots$ & $\cdots$ & $\cdots$ & $\begin{array}{c}0.100 \\
(1.81)\end{array}$ & 0.687 & 2.283 & -0.617 \\
\hline$\cdots$ & $\cdots$ & $\cdots$ & $\cdots$ & $\begin{array}{c}0.070 \\
(1.60)\end{array}$ & 0.602 & 1.531 & -0.797 \\
\hline$\cdots$ & $\cdots$ & $\cdots$ & $\cdots$ & $\begin{array}{c}-0.600 \\
(2.76)\end{array}$ & 0.842 & 2.718 & -0.561 \\
\hline$\cdots$ & $\cdots$ & $\cdots$ & $\begin{array}{c}0.180 \\
(3.65)\end{array}$ & $\ldots$ & 0.598 & 2.161 & -0.252 \\
\hline $\begin{array}{c}-0.400 \\
(2.40)\end{array}$ & $\cdots$ & $\ldots$ & $\ldots$ & $\begin{array}{c}-0.690 \\
(4.55)\end{array}$ & 0.804 & 2.774 & -0.240 \\
\hline $\begin{array}{c}0.250 \\
(2.72)\end{array}$ & $\ldots$ & $\ldots$ & $\begin{array}{c}0.140 \\
(2.43)\end{array}$ & $\ldots$ & 0.560 & 2.039 & -0.330 \\
\hline$\ldots$ & $\cdots$ & $\cdots$ & $\ldots$ & $\begin{array}{c}-0.180 \\
(2.61)\end{array}$ & 0.856 & 2.001 & -0.530 \\
\hline$\cdots$ & $\cdots$ & $\ldots$ & $\ldots$ & $\begin{array}{c}-0.140 \\
(2.73)\end{array}$ & 0.876 & 2.204 & -0.760 \\
\hline$\ldots$ & $\ldots$ & $\begin{array}{c}0.003 \\
(3.91)\end{array}$ & $\ldots$ & $\ldots$ & 0.901 & 2.315 . & 0.570 \\
\hline
\end{tabular}


TABLE 4

SHIFT-SHARE MODEL: INDUSTRIAL-MIX HYPOTHESIS

\begin{tabular}{|c|c|c|c|c|c|}
\hline \multirow[b]{2}{*}{ Industry Group } & \multirow{2}{*}{$\begin{array}{l}\text { Constant } \\
\text { Term }\end{array}$} & \multicolumn{4}{|c|}{ INDEPENDENT VARIABLES } \\
\hline & & $\left(E_{1 /} / E_{1}\right)$ & $\left(\mathrm{P}_{0} / \mathrm{P}_{\mathrm{c}}\right)$ & $\left(W_{0} / W_{c}\right)_{u}$ & $\left(\mathrm{U}_{\mathrm{o}} / \mathrm{U}_{\mathrm{c}}\right)$ \\
\hline $\begin{array}{l}\text { ONTARIO: ALL } \\
\text { INDUSTRIES }\end{array}$ & -1.86 & $\ldots$ & $\ldots$ & $\ldots$ & $\ldots$ \\
\hline $\begin{array}{l}\text { INDUSTRIES WITH } \\
\text { L. } Q>1 \text { (Total) }\end{array}$ & -6.05 & $\begin{array}{r}0.810 \\
(1.89)\end{array}$ & $\begin{array}{l}19.190 \\
(2.33)\end{array}$ & $\begin{array}{c}-0.490 \\
(2.83)\end{array}$ & $\ldots$ \\
\hline Rubber Industries & -2.99 & $\ldots$ & $\ldots$ & $\ldots$ & $\ldots$ \\
\hline $\begin{array}{l}\text { Printing/Publishing and } \\
\text { Allied Industries }\end{array}$ & 0.03 & $\cdots$ & $\ldots$ & $\ldots$ & $\ldots$ \\
\hline Primary Product Industries & 1.06 & $\begin{array}{l}1.400 \\
(3.97)\end{array}$ & $\ldots$ & $\ldots$ & $\ldots$ \\
\hline $\begin{array}{l}\text { Metal Fabricating } \\
\text { Industries }\end{array}$ & 0.01 & $\ldots$ & $\ldots$ & $\ldots$ & $\cdots$ \\
\hline Machinery Industries & 1.26 & $\begin{array}{r}-2.220 \\
(8.02)\end{array}$ & $\ldots$ & $\begin{array}{c}-0.810 \\
(7.45)\end{array}$ & $\begin{array}{r}-1.350 \\
(5.16)\end{array}$ \\
\hline Transportation Industries & -2.61 & $\begin{array}{r}0.570 \\
(7.48)\end{array}$ & $\begin{array}{l}6.620 \\
(7.97)\end{array}$ & $\begin{array}{l}0.320 \\
(4.69)\end{array}$ & $\begin{array}{r}-0.220 \\
(4.89)\end{array}$ \\
\hline $\begin{array}{l}\text { Non-Metallic Mineral } \\
\text { Industries }\end{array}$ & -0.08 & $\ldots$ & $\ldots$ & $\ldots$ & $\ldots$ \\
\hline $\begin{array}{l}\text { Chemical \& Chemical } \\
\text { Product Industries }\end{array}$ & -0.18 & $\begin{array}{l}1.060 \\
(3.11)\end{array}$ & $\ldots$ & $\ldots$ & $\ldots$ \\
\hline $\begin{array}{l}\text { INDUSTRIES WITH } \\
\text { L. } Q<1 \text { (Total) }\end{array}$ & -0.33 & $\begin{array}{c}-0.640 \\
(3.14)\end{array}$ & $\begin{array}{r}0.370 \\
(2.04)\end{array}$ & $\begin{array}{c}-0.050 \\
(3.07)\end{array}$ & \\
\hline $\begin{array}{l}\text { Food \& Beverage } \\
\text { Industries }\end{array}$ & -0.69 & $\begin{array}{l}1.520 \\
(2.22)\end{array}$ & $\ldots$ & $\ldots$ & $\ldots$ \\
\hline Leather Industries & 0.98 & $\begin{array}{r}-12.080 \\
(4.07)\end{array}$ & $\ldots$ & $\begin{array}{c}-0.210 \\
(3.21)\end{array}$ & $\begin{array}{r}0.040 \\
(4.00)\end{array}$ \\
\hline Textile Industries & -0.05 & $\begin{array}{l}0.340 \\
(2.25)\end{array}$ & $\ldots$ & $\ldots$ & $\ldots$ \\
\hline Clothing Industries & 0.19 & $\begin{array}{l}0.240 \\
(2.07)\end{array}$ & $\ldots$ & $\begin{array}{c}-0.120 \\
(2.42)\end{array}$ & $\begin{array}{r}-0.050 \\
(2.42)\end{array}$ \\
\hline Wood Industries & -0.10 & $\ldots$ & $\ldots$ & $\ldots$ & $\begin{array}{r}-0.050 \\
(4.76)\end{array}$ \\
\hline $\begin{array}{l}\text { Furniture \& Fixture } \\
\text { Industries }\end{array}$ & 0.15 & $\begin{array}{r}-0.280 \\
(1.83)\end{array}$ & $\begin{array}{r}0.570 \\
(2.69)\end{array}$ & $\ldots$ & $\begin{array}{r}-0.030 \\
(1.66)\end{array}$ \\
\hline Paper \& Allied Product & -0.25 & $\begin{array}{c}-0.280 \\
(3.22)\end{array}$ & $\begin{array}{r}0.510 \\
(2.69)\end{array}$ & $\begin{array}{r}-0.160 \\
(2.86)\end{array}$ & $\begin{array}{r}-0.250 \\
(1.92)\end{array}$ \\
\hline $\begin{array}{l}\text { Petroleum \& Coal } \\
\text { Industries }\end{array}$ & -0.06 & $\ldots$ & $\begin{array}{l}0.160 \\
(3.04)\end{array}$ & $\ldots$ & $\ldots$ \\
\hline
\end{tabular}


TABLE 4

SHIFT-SHARE MODEL: INDUSTRIAL-MIX HYPOTHESIS (Cont.)

INDEPENDENT VARIABLES

\begin{tabular}{|c|c|c|c|c|c|c|c|}
\hline$\left(Y_{0} / Y_{c}\right)$ & $\left(\mathrm{I}_{\mathrm{A}}\right)$ & $\left(\mathrm{I}_{0}\right)_{\mathrm{U}}$ & $\left(I_{0} / I_{c}\right)_{i}$ & $\left(I_{0} / I_{c}\right)_{M}$ & $\left(I_{0} / I_{c}\right)_{T}$ & & $\begin{array}{l}\text { Watson d- } \\
\text { Statistic }\end{array}$ \\
\hline $\begin{array}{l}8.130 \\
(3.74)\end{array}$ & $\ldots$ & $\ldots$ & $\ldots$ & $\ldots$ & $\begin{array}{c}-0.800 \\
(2.93)\end{array}$ & 0.609 & 1.240 \\
\hline $\begin{array}{l}9.820 \\
(3.54)\end{array}$ & $\begin{array}{l}0,010 \\
(2.08)\end{array}$ & $\ldots$ & $\ldots$ & $\ldots$ & $\begin{array}{r}-13.650 \\
(3.49)\end{array}$ & 0.830 & 1.535 \\
\hline $\begin{array}{l}7.820 \\
(3.41)\end{array}$ & $\ldots$ & $\ldots$ & $\ldots$ & $\ldots$ & $\ldots$ & 0.538 & 2.350 \\
\hline$\ldots$ & $\begin{array}{l}1.06 \mathrm{E}_{o} \\
(2.02)\end{array}$ & $\ldots$ & $\ldots$ & $\ldots$ & $\begin{array}{c}-0.400 \\
(1.56)\end{array}$ & 0.311 & 2.600 \\
\hline$\ldots$ & $\ldots$ & $\ldots$ & $\begin{array}{c}-0.270 \\
(2.31)\end{array}$ & $\ldots$ & $\ldots$ & 0.670 & 2.166 \\
\hline$\ldots$ & $\cdots$ & $\begin{array}{c}-10.23 \mathrm{E}_{\mathrm{o}} \\
(2.44)\end{array}$ & $\ldots$ & $\ldots$ & $\ldots$ & 0.551 & 2.182 \\
\hline $\begin{array}{l}4.920 \\
(9.27)\end{array}$ & $\begin{array}{c}-0.82 \mathrm{E}_{\mathrm{o}} \\
(7.79)\end{array}$ & $\ldots$ & $\ldots$ & $\ldots$ & $\begin{array}{c}-1.770 \\
(8.47)\end{array}$ & 0.962 & 2.279 \\
\hline$\ldots$ & $\begin{array}{l}-0.53 \mathrm{E} \\
(12.15)\end{array}$ & $\ldots$ & $\ldots$ & $\ldots$ & $\ldots$ & 0.972 & 2.486 \\
\hline$\cdots$ & $\begin{array}{c}-0.40 \mathrm{E}_{\mathrm{o}} \\
(2.47)\end{array}$ & $\ldots$ & $\ldots$ & $\ldots$ & $\begin{array}{r}0.320 \\
(2.72)\end{array}$ & 0.490 & 3.064 \\
\hline$\cdots$ & $\ldots$ & $\ldots$ & $\ldots$ & $\ldots$ & $\begin{array}{r}-0.520 \\
(3.31)\end{array}$ & 0.550 & 2.119 \\
\hline $\begin{array}{c}0.650 \\
.(2.81)\end{array}$ & $\begin{array}{r}0.010 \\
(2.81)\end{array}$ & $\begin{array}{c}-16.43 \mathrm{E}_{\mathrm{o}} \\
(2.48)\end{array}$ & $\ldots$ & $\ldots$ & $\ldots$ & 0.820 & 2.363 \\
\hline$\ldots$ & $\begin{array}{l}0.001 \\
(2.71)\end{array}$ & $\ldots$ & $\ldots$ & $\ldots$ & $\ldots$ & 0.458 & 3.075 \\
\hline$\ldots$ & $\begin{array}{l}11.800 \\
(3.97)\end{array}$ & $\ldots$ & $\ldots$ & $\ldots$ & $\begin{array}{r}0.110 \\
(2.86)\end{array}$ & 0.897 & 2.662 \\
\hline$\ldots$ & $\begin{array}{c}-0.61 \mathrm{E}_{\mathrm{o}} \\
(2.48)\end{array}$ & $\ldots$ & $\ldots$ & $\ldots$ & $\ldots$ & 0.410 & 2.246 \\
\hline$\ldots$ & $\ldots$ & $\ldots$ & $\ldots$ & $\begin{array}{c}-0.180 \\
(1.76)\end{array}$ & $\ldots$ & 0.531 & 1.504 \\
\hline $\begin{array}{l}0.050 \\
(6.53)\end{array}$ & $\begin{array}{r}0.130 \\
(2.54)\end{array}$ & $\ldots$ & $\ldots$ & $\ldots$ & $\begin{array}{r}0.170 \\
(3.86)\end{array}$ & 0.945 & 1.743 \\
\hline $\begin{array}{l}0.370 \\
(2.26)\end{array}$ & $\ldots$ & $\ldots$ & $\ldots$ & $\ldots$ & $\ldots$ & 0.657 & 1.743 \\
\hline$\ldots$ & $\cdots$ & $\ldots$ & $\ldots$ & $\ldots$ & $\ldots$ & 0.868 & 3.013 \\
\hline$\ldots$ & $\ldots$ & $\ldots$ & $\begin{array}{c}0.005 \\
(1.82)\end{array}$ & $\ldots$ & $\ldots$ & 0.519 & 2.427 \\
\hline
\end{tabular}


transportation, and electrical product industries); the interregional distribution of capital formation in the i industry in four sectors (non-metallic mineral, chemical and chemical product, food and beverage, and petroleum and coal industries); the distribution of the industrial capital formation in four industries (primary product, electrical product, knitting mills, and wood industries); and the distribution of the overall capital formation in seven industries (printing/publishing, tobacco product, leather, textile, clothing, furniture and fixture, and paper and allied industries) are fairly good explanatory factors of the regional-share component. The signs of the regression coefficients are not, as one should expect, uniformarly determined. It is apparent that what a given increment of capital adds to employment will vary, both in terms of direction and magnitude, with the type of the individual industry (capital versus labor intensive), the techniques of production, the input of the other factors, and the extent to which the new capital replaces one type of production with another (Brewis, 1972, P.63). Given these varying relationships, capital formation and regional-share component cannot always be expected to follow similar trends. This explanation suggests that negative coefficients for the capital formation variables indicate that factor substitution is taking place in certain industries. Positive coefficients, on the other hand, suggest either the establishment of new firms in the province because of the availability of more industrial capital (private or public) or the attraction of industries in the province from other provinces because of infra-structure investment. To the extent that capital formation is stressed in most theories of economic growth, a convincing interpretation of the causal relationship between the regional-share component and capital formation, in any of its form, requires a depth investigation of the particular characteristics of the individual industries located in the province as well as the technological change embodied in capital formation rather than its magnitude and distribution themselves.

The regional-share hypothesis was also tested for the province of Ontario as a whole. In order to provide more meaningful results, the industries in the province were classified into two groups: (1) export-oriented industries (e.g., industries with location quotient greater than one); and (2) local industries (e.g., industries with location quotient less than one). Agglomeration economies and the distribution of industrial capital formation in the first group of industries; relative wage rates, relative unemployment rates, relative income, and the distribution of infra-structure investment in the second group of industries; and market size, industrial distribution of capital, agglomeration economies, and the share variable for the province of Ontario as a whole are fairly good explanatory factors of the province's regional-share component. All coefficients are in accord with their expected signs, except perhaps relative wages and relative unemployment, and are statistically significant. It seems véry difficult, however, to argue that relative wages and relative unemployment for the local industries ought to be rejected completely because of their positive signs. Perhaps the main reason of retaining these variables in the equation, in addition to arguments cited earlier, is the fact that high level of unem- 
ployment in the province induced unemployed labor to accept secondary type of work in the local, slow growing sectors at a relatively higher wage rate. This argument is also supported by evidence showing that the relative wages in the local sectors are lower to those in the export-sectors.

Table 4 reports the statistical results for the industrial-mix hypothesis. Interesting enough, this test indicates that the industrial-mix component of employment is fairly explained by the initial economic structure; that is the "built-up" of the region in the past $\left(\mathrm{E}_{\mathrm{ij}} / \mathrm{E}_{\mathrm{i}}\right)$, the region's economic conditions $\left(\mathrm{W}_{\mathrm{o}} / \mathrm{W}_{\mathrm{c}}, \mathrm{U}_{\mathrm{o}} / \mathrm{U}_{\mathrm{c}}, \mathrm{Y}_{\mathrm{o}} / \mathrm{Y}_{\mathrm{c}}, \mathrm{I}_{\mathrm{A}}\right)$ and market size $\left(\mathrm{P}_{\mathrm{o}} / \mathrm{P}_{\mathrm{c}}\right)$, and, more important, by the level or distribution of capital formation ${ }^{7}$. In spite of the shortcomings and weaknesses inherent in this test, the finding suggest that the rejection of the industrial-mix hypothesis either on an a priori ground or past experimentation should not be taken for granted. The present study has shown evidence that the same factors that explain the regionalshare component of employment are also, more or less, fairly good explanatory variables of the industry and province's industrial-mix component. One should note, however, that a complete understanding of the "structure" of the industry in the province and its effect on the region's economy and growth is far more complicated than the present exercise has shown. Nevertheless, the industrial-mix hypothesis in its simplified form suggests that structural deficiencies in the province can be rectified by policies acting either on the regional distribution of capital (local infrastructure investment, natural resource policies, etc.), or on changing the region's economic conditions (money wage policies, improving skills of labor, etc.). These policies may induce the expansion of already fastgrowing industries in the province and/or the establishment of new promising firms in the industry ${ }^{8}$. In general, one might argue that despite the frequent warnings regarding the applicability of the shift-share model for regional economic planning and development, the empirical confirmation of the model on a more sound basis provides some encouragement for further study and development. The application of the model on an industry-by-industry basis using time series analysis could yield, we think, more sophisticated conclusions when policy variables (e.g., taxes, duties, etc.) and the relationship between the two shift components are incorporated into the hypotheses ${ }^{9}$.

\section{CONCLUDING REMARKS}

In spite of the fact that the shift-share model has been sharply criticized in the past, the present analysis, given its limitations, has shown evidence that the model performs fairly well when structural changes and their effect on regional economies are traced over a long time span. The chief point of interest in this analysis, however, centers on the effect the capital formation variables have on both the regional-share and industrial-mix components in most of the industries in question. This has some rather interesting policy implication from the point of view of future regional economic policies. In simple words, the findings of this study suggest that government policies attempting future regional development should be 
directed towards thosefactors that can either alter the regional distribution of capital and/or change the comparative position of the region. The present analysis provides, we think, enough support and new evidence concerning the shift-share model and its usefulness in explaining and therefore predicting regional economic growth.

\section{BIBLIOGRAPHY}

Ashby L. D. (1964), The Geographical Redistribution of Employment, Survey of Current Business, Oct. 19, 13-20.

Ashby L. D. (1965), Growth Patterns in Employment by County 1940-50 and 1950-60, U.S. Department of Commerce, Office of Business Economics, Washington, D.C.

Beaud M. (1966), "Analyse Regionale-Structurelle et Plantification Regionale," Revue Ecponomique, XVII-2, pp. 254-287.

Brewis, N. T. (1972), Regional Economic Policies in Canada, (Toronto: The Macmillan Company of Canada Limited).

Brown H. J. (1969), "Shift and Share Projections of Regional Economic Growth: An Empirical Test," Journal of Regional Sciences, April 1969, pp. 1-18.

Buck T. W. (1970), "Shift Share Analysis-A Guide to Regional Policy," Regional Studies; 4, pp. 445-450.

Canada, Dominion Bureau of Statistics (1967), Manufacturing Employment and Components of Employment Change, Ontario, by County for the Period 1949-59 and 1961-64, Ottawa.

Chalmers J. A. and Beckhelm T. L. (19 $\$ b)$ ), "Shift and Share and the Theory of Industrial Location," Regional Studies, 10, pp. 15-23.

Dunn E. G. (1960), A Statistical and Analytical Technique for Regional Analysis, The Regional Science Association, Papers and Proceedings, VI, pp. 9-112.

Edwards T. A. (1976), "Industrial Structure and $\mathrm{Re}$ gional Change: A Shift-Share Analysis of the British Columbia Economy 1961-1970," Regional Studies, 10, pp. 307-317.

Floyd C. and Sirmans C. (1973), "Shift and Share Projections Revisited," Journal of Regional Science, 13, pp. 115-120.

Hellman D. A. (1976), "Shift-Share Models as Predictive Tools," Growth and Change, 7, July 1976, pp. 3-8.

H.M.S.O. (1975), The National Plan Comnd 2764.

Houston D. B. (1967), "The Shift and Share Analysis of Regional Growth: A Critique," Southern Economic Journal, 33, pp. 577-581.
Klaasen T. A. (1973), "Regional Comparative Advantage in the United States," Journal of Regional Science, 13, pp. 97-105.

Maddox J. G. and Liebharsky E. G. (1967), The Advancing South. The Twentieth Century Fund, New York, 1967.

Martin F. (1976), Regional Aspects of the Evolution of Canadian Employment, Economic Counsil of Canada, Ottawa, Canada.

Mattila J. M. (1966), A Study of Long-Run Regional Employment Growth, State Resource Planning Program, Michigan Department of Commerce.

Paris J. D. (1970), "Regional/Structural Analysis of Population Changes," Regional Studies, 4, pp. 425-443.

Randall J. N. (1973), "Shift-Share Analysis as a Guide to the Employment Performance of West Central Scotland," Scott. J. Pol. Econ., 20, pp. 1-26.

Statistics Canada (1973), Growth Patterns of Manufacturing Employment 1961-70, Cat. 31-518 Occasional, Ottawa.

Steed G.P.F. (1967), "Locational Changes: A Shift-Share Analysis of Northern Ireland's Manufacturing Mix, 1950-64," Tijdschrift Voor Econ. Soc. Geografie, Sept. Oct., pp. 265-270.

Stilwell F. J. B. (1968), "Location of Industry and Business Efficiency," Business Ratios, 2, pp. 5-15.

Stilwell F. J. B. (1969), "Regional Growth and Structural Adaptation, "Urban Studies, 6, pp. 162-178.

Stilwell F. J. B. (1970), "Further Thoughts on the Shift and Share Approach, "Regional Studies, 4, pp. 451-458.

Thirlwall A. P. (1967), “A Measure of the 'Proper' Distribution of Industry," Oxford Economic Papers, 19, pp. 46-58.

Tihanyi E. (1960), An Approach to the Study of Regional Labour Absorption: The Case of Saskatchewan, 1941-61, Saskatoon; the Canadian Center for Community Studies.

Whipple R. T. M. (1966), "Regional Differentials and Economic Planning," Australian Planning Inst. J., IV-4, 180-187.

\section{FOOTNOTES}

${ }^{1}$ See, for example, Paris (1970), Buck (1970), Stilwell (1969, 1970), Paraskevopoulos (1971), Floyd and Sirmans (1973), and many others.

${ }^{2}$ The terminology of the three shift components is not well established in the literature. Paris (1970) summarizes the equivalent terms used by different authors, as follows: For the industrial-mix component the terms that have been used are: Composition shift (Dunn, 1952), proportional shift (Whipple, 1966), industrialmix (Dominion Bureau of Statistics, Canada, (1967), structural disadvantage (Tihanyi, 1966), and structural effect (Beaud, 1966). For the competitive component the terms used by the same authors are: competition shift, differential shift, regional share, growth deficit, and regional effect. Finally, for the net relative shift, the terms used are: total shift, net relative change, labor absorptive differential, and total differential.
${ }^{3}$ The popularity of the shift-share model, because of its simplicity, either for descriptive or predictive purposes becomes evident when we pay attention to the many cases and different reasons the model has been used. Both in North America and Europe the model has been used by individual authors (Thirlwall, 1967; Steed, 1967; Brown, 1969; Randall, 1973; Dunn, 1960; Ashby, 1964; Maddox and Liebharsky, 1967) and Government agencies in Canada, (Statistics of Canada, 1973), United Kingdom (H.M.S.), 1965), and United States (Ashby, 1965) either for academic discussion or policy guidelines.

"'Relative wage rate" is defined as the ratio between wage rate in Ontario and wage rate in Canada. The wage rate is given by the ratio of manufacturing payroll in the $i$ industry to manufacturing man hours in the same industry. The wage rate for the province as a whole was calcu- 
lated in the same way. The data come from: Statistics of Canada, Manufacturing Industries of Canada, Geographical Distribution, Ottawa (various issues).

${ }^{5}$ The overall capital formation includes private and public investment in Agricultural and Fishing, Forestry, Mining, Quarrying and Oil Wells, Manufacturing, Utilities, Construction Industry, Housing, Trade Wholesale and Retail, Finance, Insurance and Real Estate, Commercial Services, and Government Department. Industrial capital, on the other hand, includes investment in total Manufacturing Industry. The data come from: Private and Public Investment in Canada, Department of Industry, Trade and Commerce, Ottawa (various Issues)

${ }^{6}$ The industries with location quotient greater than one are: rubber industries, printing, publishing and allied industries, primary metal industries, metal fabricating industries, machinery industries, transportation equipment industries, electrical products industries, non-metallic mineral products industries, chemical and chemical products industries and miscellaneous manufacturing industries.

${ }^{7}$ The industrial-mix hypothesis for the Province of Ontario as a whole was also tested on a different ground. The industrial-mix component of employment was regressed on such variables as level of wages and their changes, level of population and its change, level of income and its change, level of investment and its change, etc. In spite of the fact that the performance of these variables were quite satisfactory, the resuilts are not reported due to the fact that some of these variables are highly correlated.

${ }^{8} \mathrm{~A}$ close investigation of the performance of the Canadian manufacturing (1961-1973), in terms of number of establishment, indicates that although there had been an overall decrease in the number of establishment by $7,0 \%$, this decrease is due to small and inefficient firms (firms with $\mathrm{L} . \mathrm{Q}<1$ ). This is indicated by the fact that industries that experienced $L . Q>1$ have shown an increase of $20.63 \%$ in comparison to a decline of $-25.00 \%$ for the industries with L. $Q<1$. A similar performance is observed for the Province of Ontario. Industries with $\mathrm{L} . \mathrm{Q}>1$ have shown an increase of $22.61 \%$ and those with L.Q $<1$ a decline of $-24.00 \%$. The industries of the first category counted for $37.22 \%$ and $33.72 \%$ of the total value added and value of shipment in Canada, respectively.

The well-known argument that the two shift components are independent should be considered with care since the present study indicates that these components are highly interrelated (Table 3). Although the direction of this relationship (positive or negative) is not uniform in all sectors, as one should expect, the simultaneous determination of these components is evident. This suggests that a simultaneous model could provide more meaningful conclusions. However, this task is beyond the scope of this study. 